
$\$$ Research Square
Preprints are preliminary reports that have not undergone peer review.
They should not be considered conclusive, used to inform clinical practice,
or referenced by the media as validated information.

\title{
Territorial inequalities in children under five avoidable mortality in Colombia between 2000 and 2019: A multilevel approach
}

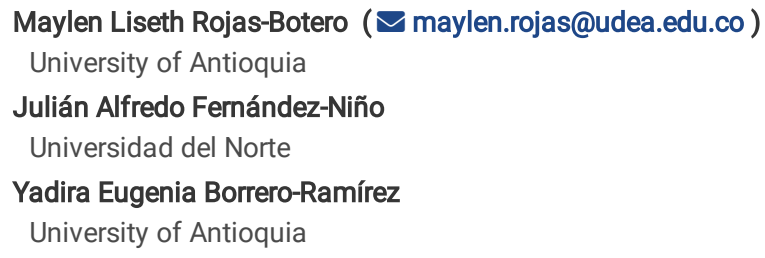

\section{Research Article}

Keywords: avoidable mortality, child mortality, health status disparities, collective effects of health disparities, social determinants of health, sociocultural territory, socioeconomic factors, ecological studies, Colombia

Posted Date: January 18th, 2022

DOI: https://doi.org/10.21203/rs.3.rs-1254701/v1

License: (c) (i) This work is licensed under a Creative Commons Attribution 4.0 International License. Read Full License 


\section{Abstract}

Aim: to evaluate territorial inequalities in children under five avoidable mortality in Colombia between 2000 and 2019.

Methods: We conducted an ecological, longitudinal, multi-group study using secondary information sources. Due to the hierarchical structure of the data, we estimated the effect of territorial characteristics on the count of avoidable deaths in children under-five years using a three-level negative binomial regression model with a random intercept by the municipality and fixed intercepts by time and departments.

Results: We found ecological relationships between children under five avoidable mortality and the proportion of adolescent births, female illiteracy, and municipality multidimensional poverty. Furthermore, the multidimensional poverty was a confounding factor for the association between the proportion of the population living in rural areas and avoidable child mortality.

Conclusions: We observed systematic and avoidable gaps in children under-five mortality in Colombia, where the territory-population binomial and the socially constructed space constitute an axis of inequality, not only the physical place itself. Implementing strategies and programs that contribute to improving the conditions of women and socioeconomic conditions in the territories should be a priority, especially, where rural population is high.

\section{Background}

Avoidable mortality in children is an indicator of premature, unnecessary, and unjust deaths in a population, insofar as they can be amenable or prevented through individual health care and relevant collective interventions on social determinants of health, resulting in years of life lost. This concept was introduced in 1976 by Rutstein et al., who identified sentinel health events assuming "that if everything had gone well, the condition would have been prevented or managed," proposing a list of diseases or events that should not -or only eventually- lead to death (1).

In the case of child mortality, high proportions of avoidability have been reported in the literature, especially in the global South, with fractions reaching up to $97.0 \%$ (2) in Uganda. In contrast, the figures observed in the UK show that $35.0 \%$ of child and adolescent deaths were classified as avoidable (3).

The proportion is also high in Colombia, although we have observed a downward trend in the last two decades. While, in $2000,93.5 \%$ of the deaths registered in the country were avoidable, this fraction was reduced to $88.5 \%$ in 2018 (4). However, there is high heterogeneity in the phenomenon distribution at the territorial level. While Páramo (Santander) showed the lowest proportion of avoidability (33.3\%) in the period 2000-2018, in another 99 municipalities, $100 \%$ of deaths in children under-five were classified as avoidable in the same period (4).

Furthermore, some conceptual models propose the territory as a social determinant of health and an axis of inequality (5). Because of its organization, infrastructure, services, and other characteristics, the territory directly influences the actual opportunities for its population to reach the highest possible level of health and well-being. Currently, theoretical-methodological tensions exist on how the territory is conceived in social research (6), corresponding to the different theoretical models of geographical thought.

In this research, the territory has been operationalized considering Colombia's political-administrative division and socio-geographical dimensions in which the characteristics of the territory-population binomial converge, such as demographic structure, geographical, and socioeconomic characteristics (Figure 1).

In previous analyses, we identified an inequality gradient in avoidable childhood mortality yielded by multidimensional municipal poverty. While in the Colombian municipalities that make up the wealthiest quintile, avoidable child mortality was 13.6 deaths per thousand live births. The rate was almost double in the poorest quintile, with 24.7 avoidable deaths per thousand live births. We also identified female illiteracy, the proportion of the population living in rurality, and the border area as axes of inequality (7).

Thus, it is appropriate to go beyond the bivariate study and advance in the joint analysis of the conditions identified as determinants of inequality at the ecological level, also considering the data's natural hierarchical structure. This will help determine if systematic and avoidable gaps in children under five mortalities in Colombia exist, where the territory-population binomial and the socially constructed space constitute an axis of inequality.

Thereby, the objective of this study was to jointly analyze, from a multilevel approach, territorial inequalities in avoidable mortality of children under five in Colombia in a period of 20 years (2000-2019).

\section{Materials And Methods}

\section{Design and study population}

We carried out an ecological, longitudinal, and multi-group study. The unit of analysis was the territory in time, in this case, the municipality in each of the fouryear periods between 2000 and 2019. We used the political-administrative distribution of Colombia for 2005; in this sense, we returned to the municipalities of segregation the municipalities created after that year. Finally, we analyzed 1117 municipalities in five four-year periods: 2000-2003, 2004-2007, 2008-2011, 2012-2015, and 2016-2019.

\section{Information sources}

We used anonymized microdata of the vital statistics of the National Department of Statistics (DANE) for 2000-2019, considering the municipality of residence and year of occurrence of the vital event. Quality analysis and database preparation were described elsewhere (4). 
Our outcome was the under-five avoidable mortality, operationalized as the count of avoidable deaths in children from 0 to 59 months, for each municipality and four-year period, using the number of live births for the same municipality-four-year period as exposure. We used the list of potentially avoidable causes of death in childhood proposed for Colombia (8) to determine the number of avoidable deaths.

\section{Exposure}

The exposure of interest was the territory, operationalized in the municipality of residence over time (unit of analysis) and its demographic, geographical, and socioeconomic conditions (Table 1).

Table 1. Explanatory variables included in the analysis

\begin{tabular}{|c|c|c|c|c|c|}
\hline ID & Availability time & Type & Options & $\begin{array}{l}\text { Ecological } \\
\text { measure-ment level }\end{array}$ & Source \\
\hline \multirow[t]{4}{*}{$\%$ of adolescent births* } & \multirow{4}{*}{$\begin{array}{l}\text { 2000-2003, 2004-2007, 2008-2011, } \\
2012-2015,2016-2019\end{array}$} & \multirow{4}{*}{$\begin{array}{l}\text { Qualitative, } \\
\text { ordinal }\end{array}$} & 1. $0.0 \%-21.2 \%$ & \multirow[t]{4}{*}{ Aggregate } & \multirow[t]{4}{*}{ Born alive, DANE } \\
\hline & & & 2. $21.3 \%-25.8 \%$ & & \\
\hline & & & 3. $25.9 \%-29.9 \%$ & & \\
\hline & & & 4. $30.0 \%-100.0 \%$ & & \\
\hline \multirow{4}{*}{$\begin{array}{l}\% \text { female illiteracy }(>15 \\
\text { years)* }\end{array}$} & \multirow[t]{4}{*}{2018} & \multirow{4}{*}{$\begin{array}{l}\text { Qualitative, } \\
\text { ordinal }\end{array}$} & 1. $0.6 \%-4.9 \%$ & \multirow[t]{4}{*}{ Aggregate } & Census, 2018 \\
\hline & & & 2. $5.0 \%-6.7 \%$ & & DANE \\
\hline & & & 3. $6.8 \%-9.1 \%$ & & \\
\hline & & & 4. $9.2 \%-27.1 \%$ & & \\
\hline \multirow[t]{4}{*}{$\begin{array}{l}\% \text { rural population in the } \\
\text { municipality* }\end{array}$} & \multirow[t]{4}{*}{$\begin{array}{l}\text { 2000-2003, 2004-2007, 2008-2011, } \\
2012-2015,2016-2019\end{array}$} & \multirow[t]{4}{*}{$\begin{array}{l}\text { Qualitative, } \\
\text { ordinal }\end{array}$} & 1. $0.0 \%-42.0 \%$ & \multirow[t]{4}{*}{ Aggregate } & \multirow[t]{4}{*}{$\begin{array}{l}\text { Population projection, } \\
\text { DANE }\end{array}$} \\
\hline & & & 2. $42.1 \%-62.2 \%$ & & \\
\hline & & & 3. $62.3 \%-76.7 \%$ & & \\
\hline & & & 4. $76.8 \%-100.0 \%$ & & \\
\hline \multirow{2}{*}{$\begin{array}{l}\text { Municipality in border } \\
\text { area }\end{array}$} & \multirow[t]{2}{*}{ 2000-2019 } & \multirow{2}{*}{$\begin{array}{l}\text { Qualitative, } \\
\text { nominal }\end{array}$} & 1. Yes & \multirow[t]{2}{*}{ Global } & \multirow[t]{2}{*}{ Law 191 of 1994} \\
\hline & & & 2. No & & \\
\hline \multirow[t]{3}{*}{ Municipal category** } & \multirow[t]{3}{*}{$\begin{array}{l}\text { 2000-2003, 2004-2007, 2008-2011, } \\
\text { 2012-2015, 2016-2019 }\end{array}$} & \multirow[t]{3}{*}{$\begin{array}{l}\text { Qualitative, } \\
\text { ordinal }\end{array}$} & $\begin{array}{l}\text { 1. Categories } \\
\text { Special and } 1\end{array}$ & \multirow[t]{3}{*}{ Global } & Law 136 of 1994 \\
\hline & & & $\begin{array}{l}\text { 2. Categories } 2, \\
3,4 \text { and } 5\end{array}$ & & \multirow{2}{*}{$\begin{array}{l}\text { General Accounting } \\
\text { Office of the Nation }\end{array}$} \\
\hline & & & 3. Category 6 & & \\
\hline \multirow{4}{*}{$\begin{array}{l}\text { Municipal } \\
\text { multidimensional } \\
\text { poverty* }\end{array}$} & \multirow[t]{4}{*}{2018} & \multirow{4}{*}{$\begin{array}{l}\text { Qualitative, } \\
\text { ordinal }\end{array}$} & 1. $4.5-30.2$ & \multirow[t]{4}{*}{ Global } & Census, 2018 \\
\hline & & & 2. $30.3-40.8$ & & \multirow[t]{3}{*}{ DANE } \\
\hline & & & 3. $40.9-52.4$ & & \\
\hline & & & 4. $52.5-98.5$ & & \\
\hline
\end{tabular}

* The categorization was carried out using the observed distribution of the variable, starting from the quartiles

** In each four-year period, the modal category was assigned

The percentage of adolescent births was obtained by dividing the number of births to women under 19 years by the total number of births. Female illiteracy (in women over 15 years of age) is available only for 2018, a measure obtained from the census. It corresponds to the proportion of women aged 16 and over who cannot read or write among the total of women of the same age group. The rural population corresponds to the percentage of people residing in rural centers and dispersed towns to the total projected population. Municipalities adjacent to the limits of Colombia, whose economic and social activities are directly influenced by the border phenomenon, were categorized as border areas (Law 191 of 1994).

The municipal category considers the population and the current income of the territory. Meanwhile, the municipal poverty with a census source -a measure not comparable with the multidimensional poverty index with a National Quality of Life Survey source-contains five dimensions: educational level in the home, conditions of childhood and youth, health, work, and housing conditions, and access to household public services. In turn, these five dimensions involve 15 indicators. Households with deprivation in at least $33.3 \%$ of the indicators are considered to be in a situation of multidimensional poverty (9).

\section{Data processing and statistical analysis}

Initially, we performed an exploratory analysis of the data. Then, we built a negative binomial regression model because we observed over-dispersion. In the negative binomial regression model, the measure of the Poisson distribution is a random variable drawn from the Gamma distribution, which introduces an 
additional free parameter. The hierarchical structure of the data required a multilevel approach. Therefore, we used the time (municipality-quadrennium) at level-1, the municipality at level 2, and the department of residence at level 3 (Figure 2).

We adjusted four negative binomial regression models. The first model, without hierarchical structure, included the proportion of adolescent births, the percentage of the population living in rural areas, municipality in border area, female illiteracy, and municipality category as explanatory variables. In the second model, we took up the explanatory variables of the first model, but we also defined the hierarchical structure of the data, including, in the first level, the municipality in time and a random interception at the municipality level. In the third model, we added a fixed intersection for the departmental level. Finally, in the fourth model, we included municipal multidimensional poverty. The association measures corresponded to standardized mortality ratios (SMRs) with $95 \%$ confidence intervals.

To determine the applicability of the multilevel approximation, we calculated the intraclass correlation index for a linear model and the test for the final model. Precision was evaluated with the standard error (SE) of the explanatory variables. We used the Wald statistic to determine the importance of the parameters. In addition, we used the Akaike and Bayesian information criteria (AIC and BIC) to evaluate the model's goodness of fit, understanding that lower values indicate a better fit.

We used the statistical program StataMP v17® for data analysis. Stata license 501709220598.

\section{Results}

Between 2000 and 2019, there were 216809 avoidable deaths in children under five in Colombia (91.3\% of all registered deaths). We analyzed 1117 municipalities in five four-year periods, nested in 33 departments. The characteristics of the municipalities are below.

Table 2. Demographic, geographic, and socioeconomic characteristics of the municipalities analyzed

\begin{tabular}{|c|c|c|c|c|c|}
\hline & \multicolumn{5}{|c|}{ Quadrennium } \\
\hline & $2000-2003$ & 2004-2007 & 2008-2011 & 2012-2015 & 2016-2019 \\
\hline Avoidable deaths in children $<5(n)$ & 62308 & 50922 & 40704 & 32499 & 30376 \\
\hline Live births (n) & 2878293 & 2857370 & 2721212 & 2659695 & 2573785 \\
\hline Avoidable Mortality Rate in children $<5$ per thousand $\mathrm{lb}$ & 21.6 & 17.8 & 15.0 & 12.2 & 11.8 \\
\hline \multicolumn{6}{|l|}{$\%$ of deliveries in adolescents * } \\
\hline & $24.6(7.2)$ & $26.1(7.4)$ & $26.9(6.6)$ & $26.5(7.4)$ & $24.1(7.3)$ \\
\hline Min - Max & $0-100$ & $0-100$ & $0-52.7$ & $0-100$ & $0-100$ \\
\hline \multicolumn{6}{|l|}{$\%$ of rural population* } \\
\hline & $59.9(24.0)$ & $58.9(24.0)$ & $58.0(24.0)$ & $57.2(23.9)$ & $56.3(24.0)$ \\
\hline Min - Max & $0.2-100$ & $0.2-100$ & $0.1-100$ & $0.1-100$ & $0.1-100$ \\
\hline \multicolumn{6}{|l|}{ Municipality category (\%) } \\
\hline Special - Cat 1 & 1.8 & 1.9 & 2.0 & 2.3 & 2.9 \\
\hline Cat 2. 3. 4, and 5 & 12.4 & 7.3 & 7.6 & 8.3 & 8.1 \\
\hline Cat 6 and not categorized & 85.8 & 90.9 & 90.4 & 89.1 & 89.0 \\
\hline
\end{tabular}

Multidimensional poverty (2018)

\begin{tabular}{ll}
\hline & $41.7 \%(17.3 \%)$ \\
\hline Min - Max & $4.5-98.5$ \\
\hline
\end{tabular}

Female illiteracy (>15) (2018)

\begin{tabular}{ll}
\hline & $7.2 \%(3.5 \%)$ \\
\hline Min - Max & $0.6 \%-27.1 \%$ \\
\hline Border area & \\
\hline P. & $11.2 \%$ \\
\hline
\end{tabular}

* We categorize this variable according to its quartiles to include them in the regression models

Page $4 / 12$ 
As indicated, we built four negative binomial models for explaining the avoidable mortality in children under five. From the first model (Table 3), we identified associations between avoidable child mortality and the proportion of births in adolescents, female illiteracy, the proportion of the population living in rural areas, border areas, and the municipality category.

Afterward, we found that the second model, with the multilevel approach, provided a better approximation for the analysis (, $p=0,000)$; with this model, we observed a considerable decrease in the magnitude of the association with births in adolescents and that the association with the municipality category disappeared.

The third model gains plausibility and modifies the magnitude of the association between avoidable mortality in children and the border area.

Meanwhile, the last model, which adjusts by the multidimensional poverty, maintained the association between avoidable mortality in Colombian children and a proportion of births in adolescents greater than $30.0 \%$ and female illiteracy greater than $6.8 \%$. The association with the population residing in rural areas disappeared, showing a confounding effect at the ecological level (Table 3 ).

Table 3. Multivariate and multilevel negative binomial regression models 


$\begin{array}{llll}\text { Model 1 } & \text { Model 2 } & \text { Model 3 } & \text { Model 4 } \\ \text { SMR }(95 \% \mathrm{Cl}) & \operatorname{SMR}(95 \% \mathrm{Cl}) & \operatorname{SMR}(95 \% \mathrm{Cl}) & \operatorname{SMR}(95 \% \mathrm{Cl})\end{array}$

\begin{tabular}{cllll}
\hline \begin{tabular}{l} 
\% of deliveries in adolescents \\
\hline $0.0 \%-21.2 \%($ Ref $)$
\end{tabular} & - & & & \\
\hline $21.3 \%-25.8 \%$ & 1.04 & 1.01 & 1.00 & 1.00 \\
& $(1.01-1.08)$ & $(0.98-1.04)$ & $(0.98-1.03)$ & $(0.97-1.03)$ \\
\hline $25.9 \%-29.9 \%$ & 1.09 & 1.02 & 1.01 & 1.00 \\
& $(1.05-1.13)$ & $(0.99-1.05)$ & $(0.98-1.05)$ & $(0.97-1.03)$ \\
\hline $30.0 \%-100.0 \%$ & 1.21 & 1.09 & 1.07 & 1.05 \\
& $(1.16-1.25)$ & $(1.05-1.13)$ & $(1.03-1.11)$ & $(1.01-1.08)$ \\
\hline
\end{tabular}

\begin{tabular}{|c|c|c|c|c|}
\hline \multicolumn{5}{|l|}{ Female illiteracy } \\
\hline $0.0 \%-4.0 \%$ (Ref) & - & - & - & - \\
\hline \multirow[t]{2}{*}{$4.1 \%-6.7 \%$} & 1.07 & 1.06 & 1.07 & 1.03 \\
\hline & $(1.03-1.11)$ & $(1.00-1.13)$ & $(1.02-1.12)$ & $(0.98-1.08)$ \\
\hline \multirow[t]{2}{*}{$6.8 \%-9.1 \%$} & 1.21 & 1.18 & 1.16 & 1.07 \\
\hline & $(1.17-1.26)$ & $(1.11-1.26)$ & $(1.10-1.23)$ & $(1.01-1.13)$ \\
\hline \multirow[t]{2}{*}{$9.2 \%-27.1 \%$} & 1.46 & 1.41 & 1.32 & 1.13 \\
\hline & $(1.40-1.52)$ & $(1.32-1.50)$ & $(1.24-1.40)$ & $(1.05-1.20)$ \\
\hline \multicolumn{5}{|l|}{$\%$ of rural population } \\
\hline $0.0 \%-42.0 \%$ (Ref) & - & - & - & - \\
\hline \multirow[t]{2}{*}{$42.1 \%-62.2 \%$} & 0.92 & 0.98 & 0.99 & 0.96 \\
\hline & $(0.89-0.96)$ & $(0.93-1.03)$ & $(0.95-1.03)$ & $(0.92-1.00)$ \\
\hline \multirow[t]{2}{*}{$62.3 \%-76.7 \%$} & 0.95 & 0.98 & 1.01 & 0.96 \\
\hline & $(0.92-0.99)$ & $(0.93-1.03)$ & $(0.97-1.16)$ & $(0.91-1.00)$ \\
\hline \multirow[t]{2}{*}{$76.8 \%-100.0 \%$} & 1.05 & 1.06 & 1.09 & 1.00 \\
\hline & $(1.01-1.09)$ & $(1.00-1.12)$ & $(1.03-1.15)$ & $(0.95-1.06)$ \\
\hline \multirow[t]{2}{*}{ Border area } & 1.13 & 1.12 & 0.99 & 1.02 \\
\hline & $(1.09-1.17)$ & $(1.05-1.20)$ & $(0.92-1.08)$ & $(0.95-1.11)$ \\
\hline
\end{tabular}

Municipality category

\begin{tabular}{lllll}
\hline Special and category 1 (Ref) & - & - & - & - \\
\hline Categories $2,3,4$ and 5 & 1.08 & 1.05 & 1.04 & 1.03 \\
& $(1.01-1.16)$ & $(0.98-1.13)$ & $(0.97-1.11)$ & $(0.97-1.10)$ \\
\hline Category 6 and not categorized & 1.10 & 1.07 & 1.04 & 1.03 \\
& $(1.03-1.18)$ & $(0.99-1.16)$ & $(0.97-1.12)$ & $(0.96-1.11)$
\end{tabular}

Multidimensional poverty

\begin{tabular}{ll}
\hline $4.5-30.2$ (Ref) & - \\
\hline $30.3-40.8$ & 1.09 \\
& $(1.03-1.15)$
\end{tabular}




\begin{tabular}{|c|c|c|c|c|}
\hline & Model 1 & Model 2 & Model 3 & Model 4 \\
\hline & SMR $(95 \% \mathrm{Cl})$ & SMR (95\% Cl) & $\operatorname{SMR}(95 \% \mathrm{Cl})$ & $\operatorname{SMR}(95 \% \mathrm{Cl})$ \\
\hline \multirow[t]{2}{*}{$40.9-52.4$} & & & & 1.16 \\
\hline & & & & $(1.09-1.23)$ \\
\hline \multirow[t]{2}{*}{$52.5-98.5$} & & & & 1.43 \\
\hline & & & & $(1.33-1.54)$ \\
\hline
\end{tabular}

\begin{tabular}{lllll}
\hline Model fitting & & & & \\
\hline AIC & 34.730 .3 & 32.995 .0 & 32.457 .4 & 32.358 .1 \\
\hline BIC & 34.849 .6 & 33.120 .9 & 32.795 .3 & 32.716 .0 \\
\hline
\end{tabular}

SMR = Standardized Mortality Ratio

As observed in Model 4 and Figure 3, we find a strong association between municipal multidimensional poverty and avoidable mortality in children under-five years of age, with a marked inequality gradient and worse results for the municipalities with the highest multidimensional poverty.

Thus, when comparing between extremes, the municipalities with the highest poverty have a standardized ratio of avoidable mortality in children, $43 \%$ higher than the municipalities with the lowest poverty (Model 3). Similarly, when $30 \%$ or more of births in the municipality occur in adolescents, there is an increase of $5.0 \%$ in the children's standardized avoidable mortality ratio. Said increase is $7.0 \%$ when illiteracy in women is between $6.8 \%$ and $9.1 \%$, and a higher increase of $13.0 \%$, when female illiteracy exceeds $9.2 \%$.

\section{Discussion}

The differences in the magnitude of avoidable mortality in children under five years of age between socially constituted groups are a reference for the degree of inequity in health in a population. In this sense, the gaps found in this work do not only indicate the presence of inequalities in medical-health care but also constitute an expression of structural injustices and the need to implement public policies aimed at positively impacting the social determinants that originate these differences.

In the previous analysis, and based on a bivariate analysis, socioeconomic, geographic, and demographic determinants of the territories were identified related to the heterogeneous distribution of avoidable mortality of children under five years of age in Colombian municipalities. On this occasion, we progressed in understanding the phenomenon, jointly considering the different social determinants of health and the hierarchical structure of the data.

As observed in the results, recognizing the absence of independence in the observations alone, the association with the municipality category and the border zone disappeared (Models 2 and 3). Then, by adjusting for multidimensional poverty, the association with the proportion of the population residing in rural areas also disappeared. These findings coincide in showing that the physical space alone is not a determinant of health. It involves the socio-cultural territory: socially constructed space, including educational and work conditions, health services quality, access, and affordability, public services, and population opportunities, including children and youth. These must be intervened, and all the actors in society must be incorporated to guarantee that the risk of dying for children under five from avoidable causes is not increased due to the place of birth or residence.

One of the associations that remained was the relationship between the proportion of births in adolescents and child avoidable mortality, although it was modified with the multivariate analysis. This relationship has been repeatedly reported in the literature. From the individual level, it has been found that the children of adolescent mothers have a higher risk of dying, especially in poor households (10). Moreover, from the ecological perspective, higher mortality rates (neonatal, infant, and children) have been observed in states with high proportions of births by adolescent mothers (11) and countries with high adolescent fertility rates (12).

It is worth mentioning that Neal et al. obtained similar results when they evaluated the evidence from 45 low-and middle-income countries regarding the impact of maternal age on neonatal mortality. In this case, the offspring of adolescent mothers (under 16 years of age) presented a higher risk of neonatal death than children of adult mothers, with marked differences among countries. Furthermore, this association was maintained after adjusting for socioeconomic and demographic characteristics and health care access. (13).

Similar findings were found by Sharma et al. (14). They reported that the children of adolescent mothers between 12 and 15 living in rural areas of Nepal had an excess of neonatal mortality compared to the children of older women, adjusting for socioeconomic factors, low birth weight, preterm birth, and small size for gestational age.

Several biological and physiological causal pathways have been suggested for this association at the individual level. This association can be exacerbated by adverse socioeconomic conditions and barriers to prenatal care access. An increased risk of low birth weight and prematurity in children of adolescent mothers has been associated with biological immaturity during pregnancy $(15,16)$; mother-fetus nutrient competition induced nutritional deficiencies $(17,18)$; the increased risk of hypertensive disorders and preeclampsia in pregnant adolescents $(19,20)$; and aspects related to physiological immaturities, such as reduced blood supply to the uterus and cervix (21) and the reduced placental transport in adolescents (22). 
In addition, we found a strong association between female education and infant and childhood mortality. This relationship has been frequently reported in the literature, both individually and collectively. In this sense, higher child mortality rates have been observed among children of women with a lower educational level (23). Meanwhile, a systematic review of female education and child health in 175 countries between 1970 and 2009 indicated that approximately half of the reduction in child mortality could be attributed to the increase of schooling of young women worldwide (24).

It is worth mentioning that some studies involving low-income countries have shown that the mother's education can explain a higher part of the variation in infant and child mortality than the household's economic resources $(25,26)$. Similarly, studies have concluded that this association remains after adjusting for socioeconomic conditions. Research considering both determinants has found that maternal education and household wealth are independently associated with infant mortality (26).

Among the possible explanations, it has been proposed that the mothers' education increases health awareness and high-order cognitive skills, encouraging them to seek opportune health services and promoting practices that benefit the child's well-being $(27,28)$. Furthermore, some researchers have argued that in addition to developing skills and competencies that facilitate interaction with health bureaucracies, education leads to more equitable gender attitudes and greater autonomy (29). This has a positive impact on the empowerment of sexual and reproductive health and better living conditions for children.

This study presents some limitations inherent to the use of secondary sources of information. In addition, it should be noted that the scope of ecological studies cannot definitively explain whether these determinants have the same direction and magnitude of association at an individual level. In this case, whether those socio-geographical determinants have a greater or lesser effect on the risk of a child dying before reaching the age of five due to an avoidable cause. The joint distribution of the characteristics of the study at the individual level is unknown, making it impossible to determine whether the children dead by avoidable causes were the same presenting the highest exposure to poverty, mothers' low education, or whether they were children of adolescent mothers. Therefore, the reader should be aware that the results found for municipalities should not be concluded for individuals and, thus, avoid the cross inference between levels, known as the ecological fallacy.

Furthermore, we found that the main determinant of avoidable mortality in children corresponds to multidimensional municipal poverty. However, this indicator is exclusively for 2018 and is not comparable with other poverty measures in the territories. Therefore, it is impossible to adjust for the variation of this measurement over time, which may lead to imprecisions that may be underestimated. Nevertheless, the socioeconomic conditions of the territories do not vary strongly in short periods. In the inequality analysis, the relative poverty differences between the municipalities are more important than the absolute differences.

Additionally, we emphasize that the statistical models are not perfect; there are multiple possible and valid models to explain the observed phenomena. In this case, we worked with the available information for the Colombian territories. However, this does not mean that the determinants in this study are the only with an important effect on children under five avoidable mortality in Colombian municipalities. Thus it is pertinent to continue with the analysis of this phenomenon from other theoretical-methodological approaches.

\section{Conclusion}

Finally, this study confirms the existence of socio-geographical inequalities among municipalities regarding children's avoidable mortality in Colombia. At the same time, it shows the importance of the socially constructed space on the actual opportunities to live a dignified life and survive early childhood. Also, it highlights the effect of socioeconomic gaps between territories on the unjust distribution of avoidable mortality. It confirms the independent association between female education, births in adolescents, and poverty of the territory-population binomial on avoidable mortality in children under-five, characteristics on which targeted interventions should be planned, closing unfair and unjust gaps, and advancing compliance with children's rights, especially in the most disadvantaged population.

\section{Declarations}

Ethical Approval and Consent to participate

According to Resolution 8430 of 1993 of Colombia, this research was classified as risk-free because we used secondary and anonymized sources of information. In addition, by making use of data grouped by territories, the data protection of the subjects is guaranteed. In this sense, it was not necessary to apply an informed consent to participate in the study. Finally, this study is part of a doctoral thesis endorsed by the Research Ethics Committee of the Facultad Nacional de Salud Pública of Universidad de Antioquia (Cl 341-2018).

Consent for publication

Not applicable

Availability of data and materials

The datasets supporting the conclusions of this article are all available on the web. Microdata with the births and non-fetal deaths of children between 0 and 5 years are available on the DANE Vital Statistics website (https://www.dane.gov.co/index.php/estadisticas-por-tema/demografia-y-poblacion/nacimientos-ydefunciones). Meanwhile, the indicators from the 2018 census are available at https://www.dane.gov.co/index.php/estadisticas-por-tema/demografia-ypoblacion/censo-nacional-de-poblacion-y-vivenda-2018; the population projections are at https://www.dane.gov.co/index.php/estadisticas-portema/demografia-y-poblacion/proyecciones-de-poblacion; and the categorization of the municipalities is available on the page of the General Accounting Office of the Nation (https://www.contaduria.gov.co/categorizacion-de-departamentos-distritos-y-municipios)

Page $8 / 12$ 
Funding

This research was funded by the Grupo de Investigación Demografía y Salud of the Facultad Nacional de Salud Pública, Universidad de Antioquia (Act 01 of 2018), and by the Administrative Department of Science, Technology and Innovation -Colciencias- (national doctorate grant 647 of 2014 ). The sponsors were not involved in any way in the study design, data collection and analysis, the decision to publish this work, or the preparation of the manuscript.

Authors' contributions

MLRB designed and conceptualized the study, conducted data analysis and drafted the manuscript. JAFN \& YEBR have guided the formulation of the research gap, supported during study conceptualization and in analysis, reviewed and edited the writing, and production of the final version of the paper. All authors read and approved the final manuscript.

\section{Competing interests}

The authors declare no competing interests.

Acknowledgements

To the Demografía y Salud research group and the Doctorate in epidemiology, from the Facultad Nacional de Salud Pública. To COLCIENCIAS, for the scholarship-credit with which the MLRB was able to pursue the doctorate. To all the people who read the work, made suggestions and accompanied the process. Thanks.

Authors' information

\section{Maylen Liseth Rojas-Botero}

Professional in Health Information System Management. Master in Epidemiology. Doctor in Epidemiology. ORCID: https://orcid.org/0000-0002-5358-6426

Julián Alfredo Fernández-Niño

Medical Doctor. Master in Public Health. Master in Science of Biostatistics. Doctor in Science of Epidemiology. ORCID: https://orcid.org/0000-0002-8948-8481

\section{Yadira Eugenia Borrero-Ramírez}

Medical Doctor, Specialist in social research, Master in Sociology, Doctor in Public Health. ORCID: https://orcid.org/0000-0003-2559-4637

\section{References}

1. Rutstein DD, Berenberg W, Chalmers TC, Child CG, Fishman AP, Perrin EB, et al. Measuring the quality of medical care: A clinical method. N Engl J Med. 1976 Mar 11;294(11):582-8.

2. Willcox ML, Kumbakumba E, Diallo D, Mubangizi V, Kirabira P, Nakaggwa F, et al. Circumstances of child deaths in Mali and Uganda: a community-based confidential enquiry. Lancet Glob Health. 2018 Jun;6(6):e691-702.

3. Office for National Statistics. Statistical Bulletin. Avoidable mortality in England and Wales: 2014 [Internet]. 2016 [cited 2021 Mar 14]. Available from: https://www.ons.gov.uk/peoplepopulationandcommunity/healthandsocialcare/causesofdeath/bulletins/avoidablemortalityinenglandandwales/2014\#almost a-third-of-deaths-in-children-and-young-people-were-from-avoidable-causes

4. Rojas-Botero ML, Borrero-Ramírez YE, Cáceres-Manrique F de M. Muertes evitables en la niñez: un análisis por departamento y municipio en Colombia (2000-2018). Rev Panam Salud Publica. 2021;46(e64):1-8.

5. Comisión para reducir las desigualdades sociales en salud en España. Propuesta de políticas e intervenciones para reducir las desigualdades sociales en salud en España. Gac Sanit. 2012 Apr;26(2):182-9.

6. Fuenzalida Díaz M, Cobs Muñoz V, Guerrero Espinoza R. El territorio como unidad de análisis en estudios sobre las determinantes sociales de la salud. Argos. 2013 Dec;30(59):086-106.

7. Rojas-Botero ML. Desigualdades territoriales entre municipios en la mortalidad potencialmente evitable de niños menores de cinco años. Colombia, 2000-2019 [Internet] [Tesis doctoral para optar al título de Doctora en Epidemiología]. [Medellín]: Universidad de Antioquia; 2021 [cited 2021 Nov 23 ]. Available from: http://tesis.udea.edu.co/handle/10495/23871

8. Rojas-Botero ML, Borrero-Ramírez YE, Cáceres-Manrique F de M. Lista de causas de muerte potencialmente evitables en la niñez: una propuesta para Colombia. Cad Saúde Pública. 2020;36(9):e00086519.

9. DANE. Medida de pobreza multidimensional de fuente censal, 2018 [Internet]. 2020 [cited 2021 Mar 16]. Available from: https://www.dane.gov.co/index.php/estadisticas-por-tema/pobreza-y-condiciones-de-vida/pobreza-y-desigualdad/medida-de-pobreza-multidimensional-defuente-censal 
10. Hajizadeh M, Nandi A, Heymann J. Social inequality in infant mortality: What explains variation across low and middle income countries? Soc Sci Med. 2014 Jan;101:36-46.

11. Oliveira GS de, Lima MCB de M, Lyra C de O, Oliveira AGR da C, Ferreira MAF. Desigualdade espacial da mortalidade neonatal no Brasil: 2006 a 2010. Ciênc Amp Saúde Coletiva. 2013 Aug;18(8):2431-41.

12. McKinnon B, Harper S, Kaufman JS. Do socioeconomic inequalities in neonatal mortality reflect inequalities in coverage of maternal health services? Evidence from 48 low- and middle-income countries. Matern Child Health J. 2016 Feb;20(2):434-46.

13. Neal S, Channon AA, Chintsanya J. The impact of young maternal age at birth on neonatal mortality: Evidence from 45 low and middle income countries. PLOS ONE. 2018 May 23;13(5):e0195731.

14. Sharma V, Katz J, Mullany LC, Khatry SK, LeClerq SC, Shrestha SR, et al. Young Maternal Age and the Risk of Neonatal Mortality in Rural Nepal. Arch Pediatr Adolesc Med. 2008 Sep;162(9):828-35.

15. Chen X-K, Wen SW, Fleming N, Yang Q, Walker MC. Increased risks of neonatal and postneonatal mortality associated with teenage pregnancy had different explanations. J Clin Epidemiol. 2008 Jul 1;61(7):688-94.

16. Lawn JE, Cousens S, Zupan J, Lancet Neonatal Survival Steering Team. 4 million neonatal deaths: when? Where? Why? Lancet Lond Engl. 2005;365(9462):891-900.

17. Lenders CM, McElrath TF, Scholl TO. Nutrition in adolescent pregnancy. Curr Opin Pediatr. 2000 Jun;12(3):291-6.

18. Scholl TO, Hediger ML, Schall JI, Khoo CS, Fischer RL. Maternal growth during pregnancy and the competition for nutrients. Am J Clin Nutr. 1994;60(2):183-8.

19. Ortiz Martínez RA, Otalora Perdomo MF, Delgado ABM, Luna Solarte DA, Ortiz Martínez RA, Otalora Perdomo MF, et al. Adolescencia como factor de riesgo para complicaciones maternas y neonatales. Rev Chil Obstet Ginecol. 2018 Nov;83(5):478-86.

20. Conde-Agudelo A, Belizán JM, Lammers C. Maternal-perinatal morbidity and mortality associated with adolescent pregnancy in Latin America: Crosssectional study. Am J Obstet Gynecol. 2005 Feb;192(2):342-9.

21. Kozuki N, Lee ACC, Silveira MF, Sania A, Vogel JP, Adair L, et al. The associations of parity and maternal age with small-for-gestational-age, preterm, and neonatal and infant mortality: a meta-analysis. BMC Public Health. 2013;13 Suppl 3:S2.

22. Hayward CE, Greenwood SL, Sibley CP, Baker PN, Challis JRG, Jones RL. Effect of maternal age and growth on placental nutrient transport: potential mechanisms for teenagers' predisposition to small-for-gestational-age birth? Am J Physiol Endocrinol Metab. 2012 Jan 15;302(2):E233-242.

23. Boyle MH, Racine Y, Georgiades K, Snelling D, Hong S, Omariba W, et al. The influence of economic development level, household wealth and maternal education on child health in the developing world. Soc Sci Med 1982. 2006 Oct;63(8):2242-54.

24. Gakidou E, Cowling K, Lozano R, Murray CJ. Increased educational attainment and its effect on child mortality in 175 countries between 1970 and 2009 : a systematic analysis. The Lancet. 2010 Sep 18;376(9745):959-74.

25. Lutz W, Kebede E. Education and Health: Redrawing the Preston Curve. Popul Dev Rev. 2018 Jun;44(2):343-61.

26. Fuchs R, Pamuk E, Lutz W. Education or wealth: which matters more for reducing child mortality in developing countries? Vienna Yearb Popul Res. 2010;8:175-99.

27. Baker DP, Leon J, Smith Greenaway EG, Collins J, Movit M. The Education Effect on Population Health: A Reassessment. Popul Dev Rev. 2011 Jun;37(2):307-32.

28. Sosnaud B, Beckfield J. Trading Equality for Health? Evaluating the Trade-off and Institutional Hypotheses on Health Inequalities in the Global South. J Health Soc Behav. 2017;58(3):340-56.

29. Behrman JR, Jejeebhoy SJ. Women's Education, Autonomy, and Reproductive Behaviour: Experience from Developing Countries. Popul Dev Rev. 1996 Dec;22(4):789.

\section{Figures}




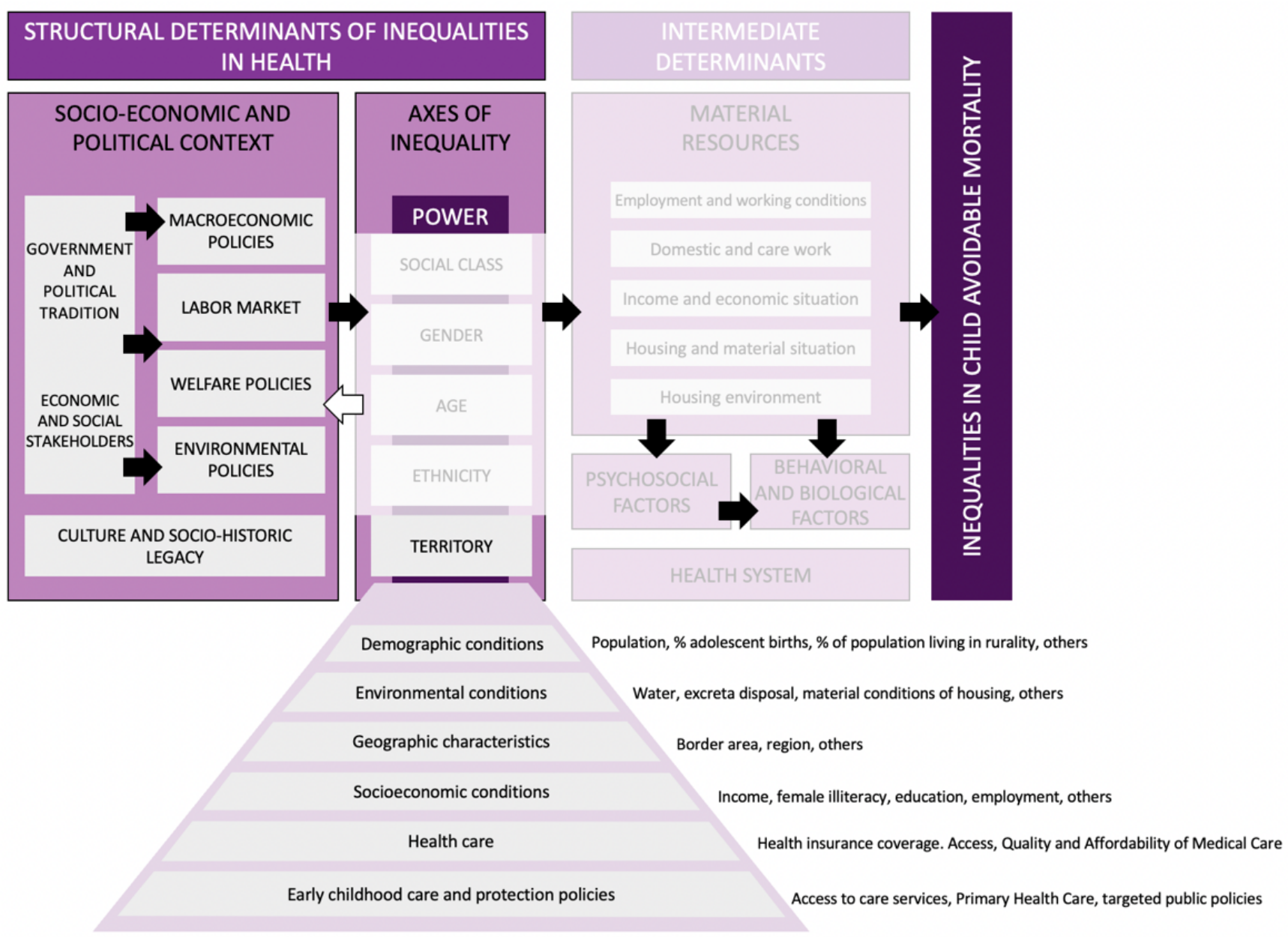

Adapted from: Commission to reduce social inequalities in health in Spain. 2010 (5)

Figure 1

Conceptual framework of the determinants of health inequalities proposed for this study

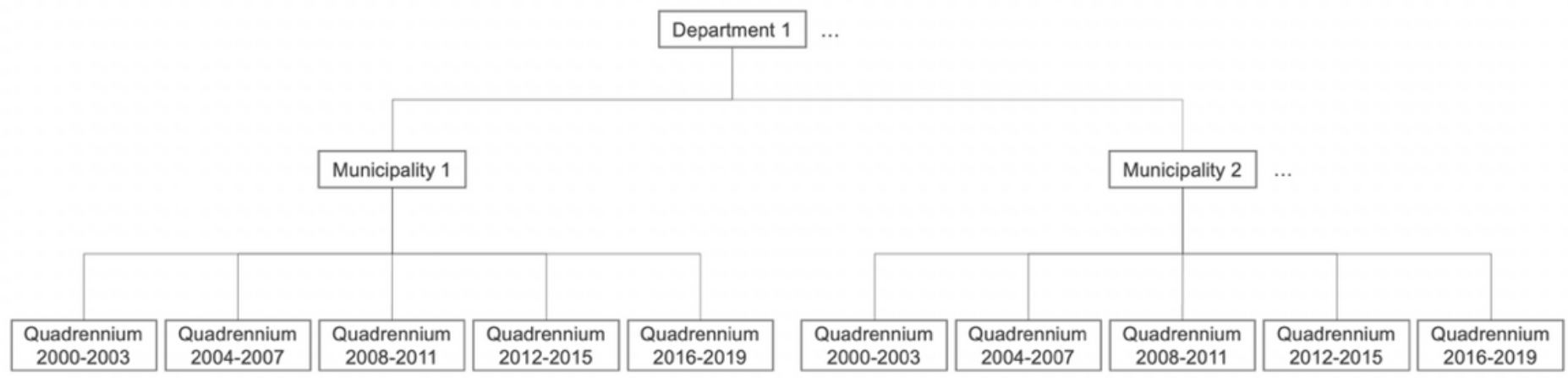

Source: Created by the authors

Figure 2

Hierarchical structure of the data 


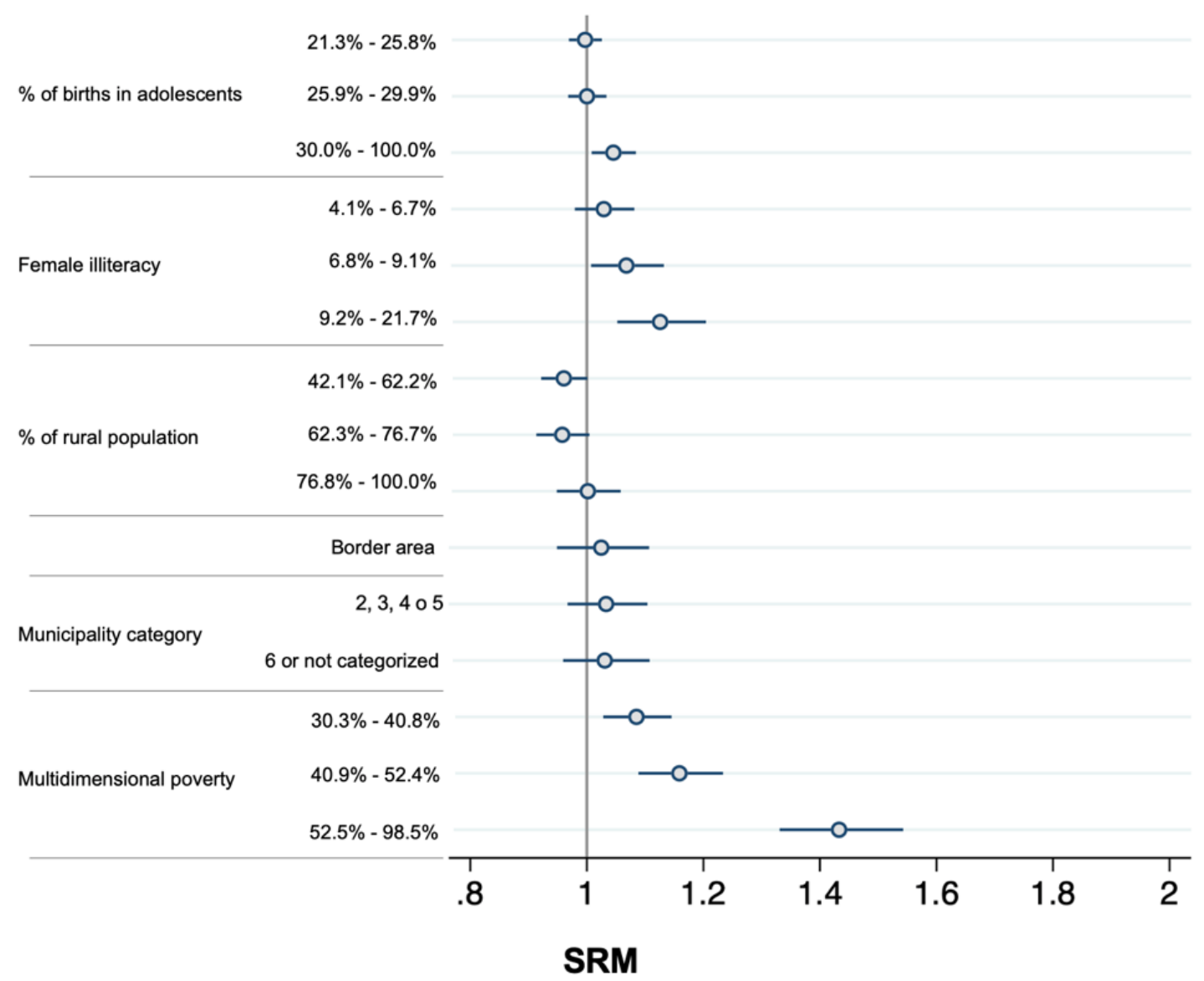

SRM obtained from a multilevel negative binomial model, with a random intercept at the municipality level and fixed intercepts in time and at the department level

\section{Figure 3}

Magnitude of the association (SRM with $95 \% \mathrm{Cl}$ ) between demographic, geographic, and socioeconomic conditions of the municipalities and the avoidable mortality of children under five years of age. Colombia, 2000-2019. 